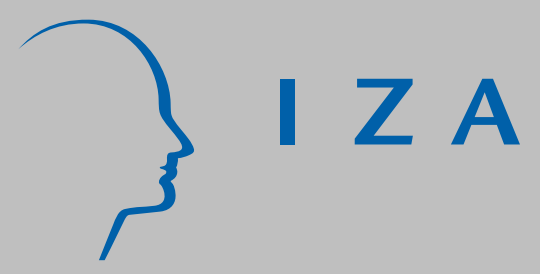

IZA DP No. 734

Sibling Rivalry: A Six Country Comparison

Stefan C. Wolter

March 2003 


\title{
Sibling Rivalry: A Six Country Comparison
}

\author{
Stefan C. Wolter \\ Swiss Coordination Centre for Research in Education, \\ University of Berne and IZA Bonn
}

\author{
Discussion Paper No. 734 \\ March 2003
}

\author{
IZA \\ P.O. Box 7240 \\ D-53072 Bonn \\ Germany \\ Tel.: +49-228-3894-0 \\ Fax: +49-228-3894-210 \\ Email: iza@iza.org
}

This Discussion Paper is issued within the framework of IZA's research area Internationalization of Labor Markets. Any opinions expressed here are those of the author(s) and not those of the institute. Research disseminated by IZA may include views on policy, but the institute itself takes no institutional policy positions.

The Institute for the Study of Labor (IZA) in Bonn is a local and virtual international research center and a place of communication between science, politics and business. IZA is an independent, nonprofit limited liability company (Gesellschaft mit beschränkter Haftung) supported by the Deutsche Post AG. The center is associated with the University of Bonn and offers a stimulating research environment through its research networks, research support, and visitors and doctoral programs. IZA engages in (i) original and internationally competitive research in all fields of labor economics, (ii) development of policy concepts, and (iii) dissemination of research results and concepts to the interested public. The current research program deals with (1) mobility and flexibility of labor, (2) internationalization of labor markets, (3) welfare state and labor market, (4) labor markets in transition countries, (5) the future of labor, (6) evaluation of labor market policies and projects and (7) general labor economics.

IZA Discussion Papers often represent preliminary work and are circulated to encourage discussion. Citation of such a paper should account for its provisional character. A revised version may be available on the IZA website (www.iza.org) or directly from the author. 
IZA Discussion Paper No. 734

March 2003

\section{ABSTRACT}

\section{Sibling Rivalry: A Six Country Comparison}

In this paper we analyse with the PISA data on literacy achievement of fifteen-year-old pupils in six member countries of the OECD, whether the fact of having many siblings affects the individual educational outcome. The hypothesis that we test is whether parents' resources matter for educational outcome. If they do and parents are constraint in their budgets, siblings will rival for the limited parental resources and thereby negatively affect educational outcome. The hypothesis is tested by regressing the literacy achievement on the number of siblings within a family and also by regressing directly forms of parental resources on the family size. We find significant family size effects in all six countries analysed but we also find significant differences in the effects between countries. Although sibling rivalry is relevant in all countries, it seems that some countries can compensate better than others and thereby achieve higher equity in the educational system.

JEL Classification: D1, I2, J2

Keywords: education, equity, parental background, family-size, PISA

Stefan C. Wolter

Swiss Co-ordination Centre for Research in Education (SKBF)

Entfelderstrasse 61

$\mathrm{CH}-5000$ Aarau

Switzerland

Tel.: + 41628352390

Fax: + 41628352399

Email: stefanwolter@yahoo.de 


\section{Introduction ${ }^{1}$}

Looking at the intergenerational patterns of educational attainment, many highly developed and industrialised countries still show a disturbingly high degree of transmission from one generation to the next (e.g. Acemoglu \& Piscke, 2001 or Dustmann, 2001 or Ermisch \& Francesconi, 2001). Although the sources for this low intergenerational mobility in education and consequently in income status and wealth are not yet clear, some results of the PISA study 2000 have clearly indicated an urgent need for a better understanding of the way the educational system deals with social differentiation. Contrary to the political statements, many indicators in the PISA data let us think that the educational system does not fulfil one of its functions, namely to reduce the impact social differences can have on educational achievement.

With the Programme for International Student Assessment (PISA) (see OECD, 2001), the OECD assessed reading, mathematical and scientific literacy in almost all of its member countries and some non-member countries. Apart from the large differences in the literacy achievement between countries, the results also showed large differences in the importance of background factors for explaining differences within and between countries ${ }^{2}$. Among the background factors with the highest explanatory value for student performance were family background variables. It proved to be one of the big advantages of the PISA data to provide a rich set of variables on the family background and the interaction between parents and children. Although these variables were significant in all countries, countries differed largely relative to the importance of socio-demographic in explaining student achievement.

In an earlier paper (Wolter \& Coradi Vellacott, 2002) we showed, that besides the usual factors like education, wealth or the occupational status of parents, family configurations can play an important role in explaining differences between students. Family size and birth-order used in economic and sociological literature as indicators for budget constraints of parents (in time and money) seem to be important for the explanation of student achievement - at least in the case of Switzerland, the country analysed in the previous study.

In this paper we extend our analysis further, to five other countries that participated in the PISA study in order to find out, whether the effects found in Switzerland can also be observed in other countries. The selection of the six countries was guided by three criteria. Firstly we chose the countries who showed the largest gap in all three literacy domains between students in the top and bottom quarters of the socioeconomic index; these are besides Switzerland Belgium and Germany. Secondly we selected the two top performing countries in reading literacy, Finland and Canada and thirdly we chose a country that showed average literacy performance but is known for an active social and family policy aimed to reduce socioeconomic differences: France.

\footnotetext{
${ }^{1}$ This article was written while the author worked as a consultant at the OECD. The author would like to thank the organisation for the stimulating working environment it provided and especially Claudia Tamassia for the provision of the data and Maja Coradi Vellacott for valuable inputs. Many colleagues at the OECD secretariat contributed with observations and suggestions to this work. The author also thanks participants at the international PISA conference in Berlin and the research seminary at the Sorbonne University, especially Catherine Sofer, the discussant, for inputs on an earlier version of the paper. The usual disclaimer holds.

${ }^{2}$ See e.g. Fertig \& Schmidt, 2002.
} 
All the countries selected in this study have in common that compulsory education is largely public and free so that there are no reasons at first sight, why budget constraints of parents should disadvantage children from big families relative to their peers coming from small families.

\section{Literature and Hypotheses}

The literature on the correlation between parents' socioeconomic status and educational outcome of students identifies three major sources for this finding: "(1) The education process in middle- and upper-class families might promote the development of attitudes that match the demand of the school-type learning environment, (2) upper class families simply provide better learning resources, and (3) upper class students enjoy direct favoritism in the formal or informal setup of the school system." (Schnabel et al., p. 179)

We assume that in reality all the three potential channels, can influence the educational outcome simultaneously ${ }^{3}$. The problem therefore is that in most cases it is nearly impossible to test them independently. In this paper we are primarily interested in the effect different amounts of resources might have on educational outcome. We are testing this question with the concept of sibling rivalry.

Sibling rivalry describes a situation in which students coming from large families suffer in their educational achievement from the fact that their parents have to divide limited household resources on more children than parents with less children under similar circumstances. Preconditions for a detrimental effect of the family size on educational outcome are:

a) that family resources matter for educational achievement,

b) that parents or at least some parents face budget constraints and

c) that some of the family resources are divisible in nature.

The latter is a necessary condition for rivalry; if all the resources were indivisible, students from poor families would be disadvantaged but the size of the family would not matter. If these three conditions are meet, and a detrimental effect of the size of the family on educational outcomes, at the same time controlling for observable differences between parents is found (formal education, employment situation, socioeconomic status and others), we should get a clear indication that parental resources and not only that status, the socialisation, the expectation of parents or their attitudes explain educational success.

\section{a) Problem of endogeneity}

Although not only economists have looked at the effects of family size on children's outcomes, the approach of Becker (1960) to the economics of the family has influenced a great number of empirical studies in the past four decades. In his initial

\footnotetext{
${ }^{3}$ e.g. Sullivan (2001) developed an operationalisation just for cultural capital. When controlling for the possession and transmission of cultural capital, a large influence of the socioeconomic status on educational outcome remains, suggesting that socioeconomic "reproduction" is created through different channels simultaneously.
} 
work on fertility decisions he introduced the notion of "quality of children" and presented the decision of families on the number of children they would have as a joint decision about quantity and quality of their descendants. Whereas this initial work was more interested in explaining the pattern of fertility in the twentieth century, Becker also discussed the implications for the investment (private and public) in human capital and the potential need for redistributional policies (see e.g. Becker \& Tomes, 1986). The work of Becker on the joint decision of parents on the quantity and quality of their children also highlighted a potential problem with the analysis of family-size effects. Family-size effects can also be the result of unobserved heterogeneity between families and not or not only because of budget constraints.

As in most other studies, we have to analyse the family size effect with the help of outcome data. It is therefore not possible to rule out the possibility completely that there is a factor that influences fertility decisions of parents, their aptitude to support their children and heritable "ability"4 jointly. In such a case the educational outcome of students from large families would not necessarily have to be the result of budget constraints and compensating those families with money would therefore not automatically help these children.

Due to this, we are not able to claim that any correlations between family size and educational outcome are of causal nature. However, the data used in this study helps us in two ways. Firstly, we have a richer data set on parents and families than used in most other studies and controlling for observable differences between families should reduce the danger of endogeneity substantially. Secondly, we can directly test our hypothesis with the help of "process" variables. These variables stand for resources (time and money) parents spend on each child. We can therefore directly test, whether the resources spend per child depend on the number of children within a family and whether a reduction of these resources affects the educational outcome. Additionally, variations of the family-size effect, like the birth-order effect (as shown in Wolter \& Coradi Vellacott, 2002), show clearly, that applications of the resource hypothesis under circumstances that do not depend on parents fertility choices, generate results that point in the same direction as the analysis of size-effects.

\section{b. Specification of variables}

Regarding the educational outcome - the dependent variable in all the empirical analyses - three different measures are commonly used. ${ }^{5}$ The most straightforward measure is educational achievement, measured in school tests ${ }^{6}$ or like in this study in comparative tests of competencies. The second measure, widely used in the empirical literature, is educational attainment, usually measured by grades or

\footnotetext{
${ }^{4}$ Behrman \& Rosenzweig (2002) highlight the problem of causality in their paper on the higher educational achievement of children of better-educated mothers. They explain the observation with correlations between schooling, heritable "ability" and assortative mating. Their results come from a twin study.

${ }^{5}$ Besides the three outcomes mentioned here, other dependent variables, like health outcome (e.g. Garg \& Morduch) have been used as well.

${ }^{6}$ Stafford (1976) uses teacher ratings of cognitive skills of pupils. Willms (1986) uses the number of siblings as one of his independent variables in explaining differences in exam results in Scotland. Hanushek (1992) uses results from the Gary Income Maintenance Experiment (which at the same time limits his sample to black, low-income families).
} 
completed school years or levels. ${ }^{7}$ Thirdly and evidently for economists, the impact on wages as an educational outcome can also be tested. ${ }^{8}$ In the ideal case, the three outcomes would be linked with an almost complete correlation and the choice of the dependent variable would not make any difference. However, we are well aware of the fact, that due to many exogenous (and endogenous) factors, high achievers in school tests are not attaining automatically higher school levels or stay longer in school and educational attainment is not always reflected in higher salaries. In order to test the effect of the family-size on educational outcomes we therefore prefer the direct test on the school performance of pupils.

Almost all studies, with the notable exception of the study of Hanushek (1992), measure the impact of contemporaneous or cumulated inputs in a cross-sectional analysis of achievement levels, a procedure that can create problems. Hanushek had the advantage of a data set with several achievement observations over time. Therefore he was able to regress changes in inputs on changes in achievement ("value-added" specification). Unfortunately, most of the data sets at hand do not allow comparing the change in achievement for individuals over time.

Besides the problem that family resources can differ in quantity and quality, another distinction should be made. Some resources are divisible and others are not. ${ }^{9}$ Indivisible resources, like the socioeconomic status of the parents ${ }^{10}$ or the location of living have the same impact on the achievement of their children independently of the size of the family. Other resources, monetary and non-monetary, are divisible, and an additional child dilutes the resources available for the other siblings. Some resources can change their nature in order to be better adapted to the size of the family. Hanushek (1992, p.86) discusses in this respect the concept of "public time" versus "private time". Public time has the nature of a public good and all children can share it without lowering the amount available for the others. Private time is the time parents spend with a single child and that therefore can not be spent on the other children. The decision how parents divide their time into private and public time will probably depend on the size of the family. When the family gets larger, parents can substitute private time with public time but as public time most probably has less educational value than private time, overall achievement will still be affected negatively. In any case, due to the fact that not all the family resources are indivisible and substitution of resources has limits, theory would predict that the size of the family has a negative effect on all siblings but the reduction in achievement should not be linear. As parents will also differ in the quality and quantity of indivisible resources, we can

\footnotetext{
${ }^{7}$ e.g. Lindert (1976), Mare \& Chen (1986a\&b), Hauser \& Kuo (1998), Bauer \& Gang (2000).

${ }^{8}$ e.g. Kessler (1991), Björklund \& Jäntti (1994).

${ }^{9}$ Behrman \& Rosenzweig (2002, p. 334) refer in their paper to information intensive versus time intensive resources that impact outcome. If it is the first effect that matters most, education of parents leads to better schooling outcomes of their children, independent of the time parents spend with each child.

10 Schoon \& Parsons (2002) show e.g. how the socioeconomic status of parents shapes the expectations and aspirations of children and by these affects their educational and occupational attainment. If we assume that parents do not need "private" time to transmit their own attitudes to the children but simply act as role models, the status of parents influences the children's behaviour independently of the size of families.
} 
predict that the negative impact of the family size will be different over families and smaller for families with a bigger share of indivisible resources ${ }^{11}$.

\section{c) Why should parental resources matter if education is free?}

Whereas most sociologists and economists would accept that all the conditions for family-size effects hold, the most recent empirical literature is to a certain extent ambiguous. ${ }^{12}$ Among those we reference in this paper, the studies from the US generally show family size effects, whereas studies in Europe found only minor effects. The only study so far that we know that compares different countries (Björklund \& Jäntti, 1994) shows the same difference in the effects between the USA and European countries. These differences are explained by the facts that education is publicly provided and free in most of the European countries and that remaining budget constraints are fought with distributional policies that target larger families with generous child allowances, free child care and other measures. Despite the undeniable effect these factors should have, we are not convinced that the provision of free education is a sufficient condition to overcome all possible budget constraints.

At least four counter arguments come easily to our mind. Firstly, although education is largely public and free, it is not homogenous in quality. PISA shows large interschool differences in the quality of schooling that is provided by public schools in some countries and it is rather obvious that wealthy parents can choose either the school or their location of residence ${ }^{13}$ more freely than others and that they can thereby also select the best schools for their children. ${ }^{14}$ Secondly, not paying tuition fees for schooling does not mean that money is not important in influencing the performance of a student. More and more families have to pay for educational resources, like computers or educational software. Thirdly, most recent research in language learning shows that children already differ significantly in their language capacities at the time of school entry. ${ }^{15}$ The socioeconomic background in which children are raised can largely explain these differences. It is therefore possible and probable that children already benefit from parental resources in their pre-school time, where as governmental regulation and the public provision of child care and education is less dense. Last but not least, money is not the only or the most important limited family resource. The time parents can spend with their children, helping them with their homework or even spending time with them on extracurricular activities can positively influence the educational outcome. The more

\footnotetext{
${ }^{11}$ According to the theories of Bourdieu (1983) or Coleman (1988) on social capital, parents differ in their possession of economic, cultural and social capital. Especially the latter two but also parts of the economic capital (prestige, power) are indivisible. In this case we would expect that children from families from a higher social class should suffer the least from a dilution of parental resources due to the family size. Regarding private time of parents, which is perhaps the most divisible resource, richer parents also have the possibility to substitute their own time with purchased child care (on the decisions to demand for nonrelative child care see e.g. Joesch \& Hiedemann, 2002 or Lundholm \& Ohlsson, 2002).

${ }^{12}$ The number of empirical studies, however, is not impressingly large and besides the study for Germany (Bauer \& Gang, 2000) and the comparative study for the USA, Finland and Sweden (Björklund \& Jäntti, 1994), we do not know of any other analysis that included European countries.

${ }_{13}$ In the case that there is no school choice for parents in the public school system, as in Switzerland, the choice of residence (catchment area) replaces the school choice.

14 Duru-Bellat (2002) argues in the case of France, that the pronounced process for more decentralised and autonomous schools leads to an increased importance of contextual factors which could provoke a widening of social gaps in educational outcome.

${ }^{15}$ See e.g. Lee \& Burkam, 2002.
} 
children a family has, the less time (ceteris paribus) parents will thus be able to spend with each of their children.

Taking these arguments together, we think that there are enough reasons to believe that family size effects can also be observed under circumstances, where tuition fees or private schools are not the major reason for budget constraints of families. The existence of a significant family size effect will, however, also depend on numerous factors like social policy, school organisation, the provision of early childhood care, the possibility of school choice and others, which vary between countries, and in countries with a federal political system even within counies. Even in a situation where family resources matter for the educational success of children, school systems and social policies might be able to compensate for the negative effects of sibling rivalry completely.

Finding strong family size effects in any case presents a challenge for educational and social policy as it indicates that for children from larger families do not have the same chances in the school system as their peers coming from small families. ${ }^{16}$

\section{A theoretical model}

In its basic version, the model that predicts a negative sibling size effect, starts from the idea that limited parental resources have to be divided by the number of siblings and therefore any increase in the family size will dilute the beneficial effect family resources can have for their children. Although this rule applies to all levels of income and endowments, it is clear that parents with different budgets of money and time face different constraints. Richer parents can purchase resources. Poor parents can not always do they same and they do not always have access to credit. Besides the possibility of using outside, non-relative sources to counterbalance the family size effect, the proportion of indivisible resources is also likely to depend on the parents' education, wealth and status.

Credit constraints, the quality of parental resources and the amount (quantity and quality) of indivisible resources therefore lead to a reinterpretation of the simple model. We would expect that children from better off parents (both in terms of income and education) would not suffer significantly from the presence of siblings. Those parents would be almost completely unconstrained. At the same time children in poor families with the same size of sibship would be significantly affected by the presence of siblings, as their parents face binding budget constraints.

We try to propose a simple extension of the classical family size model that tries to take into account the most important research findings.

\footnotetext{
${ }^{16}$ Not finding any resource effects or finding a small degree of social differentiation in the school system for fifteen-year old students does, however, not mean that equity in the whole educational system is automatically guaranteed. In the case of France, cohort studies show (see e.g. Duru-Bellat \& Kieffer, 2000) that with the mass expansion of the tertiary system, the influence of the socioeconomic background on attaining upper secondary education was reduced substantially in the second half of the last century. At the same time upper class children are still more likely to attain the prestigious "grandes écoles" at tertiary level (p. 347). So the former inequity in the chances to attain upper secondary education was shifted to the tertiary level. The same shift can be observed in most countries with a complex institutional hierarchy in the tertiary education system (e.g. Reay et al., 2001 for the UK).
} 
Outside factors, like the provision of free education, free child-care or generous child allowances also have to be taken into account when predicting the size of a sibling effect. The are especially important when searching for explanations for observed differences between countries in the sibling size effects (see header III.c).

\section{a) The family size effect}

The family size effect on the educational achievement $(E)$ of student $i$ in a family $j$ depends on the size of the parental resources $(R)$ and the number of children $(C)$.

$$
E_{i j}=\frac{R_{j}}{C_{j}}
$$

An improved model explaining the effect of the size of the sibship on educational outcome should make a distinction between indivisible $(i R)$ and divisible resources $(d R)$. Both the magnitude and proportion $(\alpha)$ of the indivisible resources will probably depend on the socioeconomic status $(\mathrm{SeS})$ of the parents. We therefore reformulate equation 1 as follows:

$$
\begin{aligned}
& R_{j}=\alpha i R_{j}+(1-\alpha) d R_{j} \\
& E_{i j}=\alpha i R_{j}+\frac{(1-\alpha) d R_{j}}{C_{j}} \\
& \text { where } \quad \alpha_{j}=\varphi\left(S e S_{j}\right), \quad \varphi>0 \\
& \qquad i R_{j}=\kappa\left(S e S_{j}\right), \quad \kappa>0 \\
& \qquad d R_{j}=\lambda\left(\operatorname{SeS}_{j}\right), \quad \lambda>0
\end{aligned}
$$

For the sake of simplicity we do not make an additional assumption about the linearity of the equations $4-6$. What becomes evident from equation 3 and 4 is that with an increasing socioeconomic status of the parents and the negative impact of one additional child in a rich family is ceteris paribus lower than in a poor family. The higher socioeconomic status translates into a smaller proportion of the resources being divisible.

We can differentiate the model further to take into account more aspects of the quality of the indivisible and divisible resources by introducing a variable that measures the cultural distance or proximity of the family to the host country $(L)$ and reformulate equation 3 . For parents originating from the host country $L$ takes the value of 1 .

$$
E_{i j}=\left(\alpha i R_{j}+\frac{(1-\alpha) d R_{j}}{C_{j}}\right) \times L_{j} \quad 0<L \leq 1
$$


Having these equations, we can rewrite equation 7 in a stylised reduced form, which provides a shortcut to the main intuitions behind the model.

$$
E_{i j}=f_{1}\left(\stackrel{+}{\operatorname{Se}^{S}}, \bar{C}_{j}, \stackrel{+}{L_{j}}\right)
$$

Equation 8 tells us that the educational achievement for children from families with a high socioeconomic background and a higher proximity to the local culture is higher, everything else being equal, but that the family size effect is negative for all families.

\section{b) The siblings - interaction effect}

Regarding the family size, equation 8 is unambiguous insofar as every additional child reduces the average educational outcome of all siblings in a family. However, as shown in the paper of Wolter \& Coradi Vellacott (2002), we find not only no significant size effects for very small families (compared to a single-child household) but in certain cases even positive effects, i.e. having at least one brother or one sister is better than being only child.

The missing link in our model is an effect similar to the peer effect in the classroom. ${ }^{17}$ We assume, that in a family brothers and sisters can act as co-educators, as role models and child carer, so that some of the time and resources that parents can not spend with their children is compensated by the interaction between children. Educational achievement is therefore a positive function of the number of siblings $(S)^{18}$. We further assume that this effect is non-linear, because with an increasing number of siblings the interaction can also become negative, e.g. when siblings disturb each other in their homework. Finally we assume that the interaction between siblings depends on the quality of siblings ${ }^{19}$, the better brothers and sisters are educated and have incorporated the cultural values of their parents, the more beneficial will their interaction with an additional child be. The quality of the children $(Q)$ will depend on the socioeconomic background and the proximity to the local culture of their parents. Equation 9 shows the peer-effect in family $j$ on the educational achievement of student $i$.

$$
\begin{array}{ll}
E_{i j}=\left(S_{j}-\mu S_{j}^{2}\right) * Q_{j}, & 0<\mu<1 \\
\text { where } Q_{j}=v\left(\operatorname{Se} S_{j} * L_{j}\right), & v>0
\end{array}
$$

As in equation 8, a shortcut of the peer-effect shows that educational achievement is a positive function of the socioeconomic background and the cultural proximity, in this

\footnotetext{
${ }^{17}$ In introducing a peer effect in our model, we follow the example of the theory on the effects of class size on educational achievement. Empirical research confirmed many times that although the time a teacher can spend per pupil falls steadily when class size increases, we can measure that the average achievement in a class follows an inverse $U$ shape. This means that there must be a counterbalancing factor, leading to an optimum in the class size. This effect is commonly called the peer effect and accounts for the positive interaction between pupils within a class. In the literature on educational production, pupils in a class are therefore also regarded as co-producers of education.

${ }^{18}$ Note that now we don't speak of the number of children but the number of siblings instead.

${ }^{19}$ Note that as in Becker, the word quality has no moral meaning.
} 
case of the number of siblings. The latter could turn negative, depending on the size of $\mu$ but should not in general.

$$
E_{i j}=f_{2}\left(\operatorname{Se}^{+} S_{j}, \stackrel{+}{S_{j}}, \stackrel{+}{L}_{j}\right)
$$

Bringing both effects, the family-size effect (7) and the peer effect (9) together in one equation (12), we can see that the structural effect of the socioeconomic background and the cultural proximity is reinforced (see summary in equation 13 and 14). For small family sizes and high quality in the interaction between siblings, the effect of an additional child, however, is not clear anymore.

$$
\begin{aligned}
& E_{i j}=\left[\left(\left(\alpha i R_{j}+\frac{(1-\alpha) d R_{j}}{C_{j}}\right) \times L_{j}\right)+\left(\left(S_{j}-\mu S_{j}^{2}\right) * Q_{j}\right)\right] \\
& E_{i j}=f_{1}\left(\operatorname{Se}_{j}^{+}, \bar{C}_{j}, \stackrel{+}{L}_{j}\right)+f_{2}\left(\operatorname{SeS}_{j}^{+}, \stackrel{+}{+}_{j},+L_{j}\right) \\
& E_{i j}=f_{3}\left(\operatorname{SeS}_{j}^{++},\left[\stackrel{+}{S}_{j}^{+} / \bar{C}_{j}\right], \stackrel{++}{L_{j}}\right)
\end{aligned}
$$

According to the model we should - in absence of any major policy intervention expect the following results in an empirical investigation:

a) Family-size effects should be concentrated among families of low socioeconomic status.

b) Family-size effects should be more pronounced for migrant families than for natives.

c) For native families and families with a high socioeconomic status, the peer effect of siblings can compensate for the size effect. In this case we not only expect the lack of the negative family size effect but do expect even cases, where having one or two siblings is better than being only child in a family.

\section{c) Policy measure effects}

Regarding the essence of the proposed model, negative family size effects can originate from or being reinforced by three sources. Firstly, there is the plain size effect, by which the amount of divisible resources is reduced by every additional child. Secondly, this effect is reinforced in those families, where the proportion of divisible resources, relative to indivisible resources is bigger. Thirdly, it can be even more reinforced (or not compensated) in the cases, where cultural distance to the host country reduces the quality of the indivisible resources and the compensatory effect of sibling interactions. 
Having these three effects in mind we can then classify possible policy measures accordingly into three categories. ${ }^{20}$ The most classical type of policy measures that should compensate (at least partially) the reduction in resources by an additional child are child allowances $(A)$. Countries do not only differ in respect to the generosity of child allowances but also whether the allowances are general (the same amount for every family) or means tested and whether they are linear (same amount per child) or increasing (or decreasing) with the number of children. ${ }^{21}$ All in all, the allowances should reduce the negative effect of the number of siblings on the divisible resources.

$E_{i j}=\left[\alpha i R_{j}+\frac{(1-\alpha) d R_{j}}{C_{j}}-A_{i j} \times C_{j}\right], \quad \frac{d E_{i j}}{d A_{i j}}>0, \frac{d A_{j}}{d C_{j}}>0$

Depending on the generosity of the allowances, they can completely offset the negative family size effect (but not the single-child effect), so that only differences between families would be left that originate in the socioeconomic differences and the migration status. If they compensate the family size effect only partially (which they generally do), we will not only still find size effects but also bigger effects for low socioeconomic groups and parents that are culturally more distant to their host country. Therefore, independent of the nature and the size of child allowances, in most countries we should observe policy measures that intentionally (or sometimes unintentionally) reduce the differences between families in indivisible resources at the same time. If e.g. the indivisible resource is the status or the influence of parents on decisions in schools, selection processes in schools should either be limited or designed in a way that they are not influenced by the social backgrounds of students. If the indivisible resource is more of the nature of having access to resources, like a big library at home or the possession of cultural goods and thereby creating a stimulating environment for children, policies could be aimed at creating access and motivating the use of public goods like libraries, art galleries or concert halls. Because of the multitude of possible measures, the relative effect they have on the educational outcome of students from different socioeconomic background is difficult to predict. Some of the measures can be well targeted at the families that need additional resources and therefore reduce the gap between families, others may just improve the level for all children and keep the gap constant. Finally some well intended measures may even increase the gap, especially if participation rates in measures depend themselves positively on the socioeconomic background of students. In general we can depart from the idea that the difference between this category of measures and the first category (we labelled child allowances) is that the resources are most likely to be spread evenly over all families and do not depend on the family size. By increasing the amount of indivisible resources relative to divisible resources in every family, however, the relative importance of the family size effect

\footnotetext{
${ }^{20}$ Note that it is not the purpose of this chapter, neither do we have the space to discuss all possible variations of the policy measures that are used in different countries. In a rather illustrative way we describe categories of measures and their intended effects.

${ }^{21}$ Besides monetary allowances, the provision of or the access to infrastructure or similar measures can have the same effect. A relevant example in the context of our empirical results is the provision of work places in schools or youth centres. As we can see in our calculations, the number of children in a household significantly reduces the probability that a child has a room of its own. The child therefore can not study or make homework under the same conditions as children from "small" families. If in this case the school or the community offers work places for students, the detrimental effect of the family size on the household infrastructure can be (partially) compensated.
} 
will be decreased. We cannot take into account all possible variations of such measures, we just introduce a factor $(\beta)$ that rises the level of indivisible resources.

$$
E_{i j}=\beta_{j} \times \alpha i R_{j}, \quad \beta>0
$$

Finally, in countries with families culturally distant to the host country, specific measures can be taken to integrate students and parents better into the society and increase their knowledge of institutions and the school system in order to give those children the same chances. It is important to note that we do not speak of migrants here. Countries can already reduce potential problems by applying a specific migration policy. In the case of Canada e.g., where immigration policy gives credit to potential migrants that are easier to integrate, we do not expect the same necessity for integration measures after immigration as in the case of Switzerland or Germany. Countries will not only differ in the policies they apply to give migrants the same chances, but also in the proportion of parents that come from culturally different environments and the distance ( $L$ in the equation) itself. Again, as for the second category of policy measures, the measures we have in mind will in general not depend on the size of the family but apply only in cases, where $L$ falls below a certain threshold that determines whether intervention is needed or not (T). In general, these measures do not depend on the family size. The integration measures ${ }^{22}$ (I) should reduce the cultural distance of migrants and have the effect of rising the quality and quantity of human capital of parents and children. These measures should reduce the size-effect (equation 17) and increase the peer-effect (equation 18) and thereby not only increase educational outcome of migrants but also make the pattern of educational outcomes more similar to the rest of the population.

$$
\begin{aligned}
E_{i j} & =\left(\alpha i R_{j}+\frac{(1-\alpha) d R_{j}}{C_{j}}\right) \times\left(L_{j}+I_{i j}\right), I=0, \text { if } T=0,0<I<1 \text { if } T=1 ; L+I \leq 1 \\
Q_{j} & =v\left[\operatorname{SeS}_{j} *\left(L_{j}+I_{i j}\right)\right]
\end{aligned}
$$

Having the three categories of policy measures integrated in the model, we get equation 19:

$$
E_{i j}=\left[\left(\left(\beta \times \alpha i R_{j}+\left(\frac{(1-\alpha) d R_{j}}{C_{j}}-A_{i j} \times C_{j}\right)\right) \times L_{j}+I_{i j}\right)+\left(\left(S_{j}-\mu S_{j}^{2}\right) * Q_{j}\right)\right]
$$

\footnotetext{
${ }^{22}$ We only consider measures that help to integrate migrants better than they are already in their host country. It is clear that a number of countries reduces the need for integration measures by applying very selective immigration rules, thereby selecting only those migrants who are culturally not too distant from the host country, or have at least a level of formal education helping them to be easily integrated. Such would be the case in Canada, who introduced in 1967 a comprehensive immigration policy with a "point"-system, that selects immigrants on the base of criteria such as age, education, language and work experience. Contrary to Canada, most European countries have no such tradition, Germany will introduce a similar law in 2003 as used in Canada though (see deVoretz, Hinte \& Werner, 2002).
} 
If the measures are well targeted, some countries should manage to offset the family size effect with the appropriate measures. Depending on the measure, the difference between migrants and natives and the differences between children coming from families with a different socioeconomic background will also be smaller. The theoretical description of policy measures, their points of intervention and the expected effects on educational outcomes also shows, that due to the multitude of possible interventions we will have difficulties to relate outcomes in a causal way with specific (and specific combinations of) measures. However, we will have to expect that due to the differences in social, educational, tax and migration policy, countries can differ in respect to the effects of social background, family size and cultural distance of migrants on educational outcome. The pattern of empirical results will give us some indications for explanations.

\section{Data}

In this paper we use the international PISA data set 2000 for Belgium, Canada, Finland, France, Germany and Switzerland. The full sample of the data has roughly 57 '000 observations. Table 1 gives an overview of the observations per countries. Due to the fact that Canada assessed in all provinces with representative samples, its number of observations is much higher than in all other countries. When using the international data set, weighting of observations therefore becomes crucial.

Reading literacy in PISA is standardised to 500 points (OECD average) with a standard error of 100 points (see OECD, 2001). Table 1 also shows the mean in the combined reading literacy scale per country and the difference in literacy achievement between students coming from the top and the bottom quartile of the socioeconomic status.

Table 1: Descriptive statistics on the six countries

\begin{tabular}{lcccc}
\hline \hline & $\begin{array}{c}\text { Mean literacy } \\
\text { score }\end{array}$ & $\begin{array}{c}\text { Differences by } \\
\text { socioeco- } \\
\text { nomic status }\end{array}$ & $\begin{array}{c}\text { Number of } \\
\text { observations }\end{array}$ & $\begin{array}{c}\text { Not of test } \\
\text { language }\end{array}$ \\
\hline Belgium & 507 & 103 & 6670 & $22.9 \%$ \\
Canada & 534 & 67 & 29687 & $9.6 \%$ \\
Finland & 546 & 52 & 4864 & $5.8 \%$ \\
France & 505 & 83 & 4673 & $5.1 \%$ \\
Germany & 484 & 114 & 5073 & $7.1 \%$ \\
Switzerland & 494 & 115 & $6100^{24}$ & $18.3 \%$ \\
\hline \hline
\end{tabular}

Data source: OECD (2001)

Most of the variables used were taken from the PISA data set, some of the variables were created from different variables in the data set. Altogether we use five groups of

\footnotetext{
${ }^{23}$ Students who speak mostly another language at home than the test language. In multilingual countries the percentage can be higher and therefore it is important to separate this measure from measure the migrational background of students. In the context of education, the language measure is as important as the migrational background.

${ }^{24}$ The data set used for Switzerland in this paper differs from the one used in the paper Wolter \& Coradi Vellacott (2002). In this paper we used the international sample of fifteen-year old students, whereas in the previous paper we had used the national sample of $9^{\text {th }}$ grade students.
} 
independent variables and two groups of dependent variables in this paper (see also table 2). The independent variables are:

1) Economic situation of families. Two variables are used as proxies for the wealth and income of families, as no direct measure is available. ${ }^{25}$ The most important variable is the so-called "ISEl" index. The index ranks students according to the occupational status of their parents. The ranking depends on the income that each occupation is likely to generate. The second variable characterises the employment situation of parents.

2) Education of parents: Two variables are used to assess the educational background of parents. The first variable is the formal education of both parents (ranked according to ISCED definition), the second variable ("closeness to education") reflects the use of education and educational and cultural goods by parents in the socialisation process of their children.

3) Migration status of parents and children: We tested several possibilities, the richness of PISA data allows us to differentiate between migrants and natives not only on the criteria of nationality. We decided to use three different (dummy) variables, because we found that they all had an independent and significant impact on reading literacy. Firstly we use a variable for the birthplace of parents, secondly one for the birthplace of the student and thirdly a dummy for the test language.

4) Family configuration: We differentiated between the classical family structure of students having both parents at home and others, and the number of siblings of course.

5) Personal characteristics: The only differentiation we made concerns the gender of the student. Girls did on average always better than boys.

The dependent variables are, on one side, the reading literacy as a proxy for educational achievement and, on the other side, variables that stand for family resources. The latter category allows us to test our hypothesis that the number of siblings affects the amount of parental resources that can be dedicated directly to each of the children.

\footnotetext{
${ }^{25}$ Note that all the information on the family background comes from the student questionnaires. For this reason it is obvious that some questions could not be asked because it was assumed, that students do not know the answer to the question.
} 
Table 2: Variable Definitions

\begin{tabular}{|c|c|}
\hline & Dependent Variables \\
\hline Reading & Achievement in reading literacy as defined in PISA \\
\hline Room & $\begin{array}{l}\text { The variable is } 1 \text { if the child has his own room and } 0 \\
\text { otherwise }\end{array}$ \\
\hline \multirow[t]{2}{*}{ Soccom } & $\begin{array}{l}\text { Composite index of three questions: How often do } \\
\text { parents discuss with you school matters, take meals with } \\
\text { you and how often do they take time to talk? }\end{array}$ \\
\hline & Independent Variables \\
\hline ISEI & $\begin{array}{l}\text { Socioeconomic index of occupational status (ranges from } \\
0 \text { to } 90)^{26}\end{array}$ \\
\hline $\begin{array}{l}\text { Parentsemployment } \\
\text { situation }\end{array}$ & $\begin{array}{l}\text { Dummy: value } 1 \text { if at least one adult in the family is fully } \\
\text { employed and } 0 \text { otherwise }\end{array}$ \\
\hline Fathers education & Formal education of father expressed in ISCED level \\
\hline Mothers education & Formal education of mother expressed in ISCED level \\
\hline $\begin{array}{l}\text { Closeness to } \\
\text { education }\end{array}$ & $\begin{array}{l}\text { Composite index of four variables: the number of books at } \\
\text { home, the frequency of discussions with parents on } \\
\text { social, political and cultural themes, the possession of } \\
\text { cultural goods and the possession of educational } \\
\text { resources }\end{array}$ \\
\hline Parents foreign born & $\begin{array}{l}\text { Dummy; value } 1 \text { if both of the parents were born outside } \\
\text { the test country }\end{array}$ \\
\hline Student foreign born & $\begin{array}{l}\text { Dummy; value } 1 \text { if the student was born outside the test } \\
\text { country }\end{array}$ \\
\hline $\begin{array}{l}\text { Other language than } \\
\text { official language }\end{array}$ & $\begin{array}{l}\text { Child speaks mostly a different language at home than } \\
\text { the language of assessment, another official languages or } \\
\text { a national dialect. }\end{array}$ \\
\hline Single headed family & Dummy; value 1 if the family has only one adult person \\
\hline Mixed family & $\begin{array}{l}\text { Dummy; value } 1 \text { if one or both of the adult persons in the } \\
\text { family are not the parents (male or female guardian) }\end{array}$ \\
\hline Other family & Dummy: value 1 if other combination of adults \\
\hline NSIB & $\begin{array}{l}\text { Number of siblings. The variable is also used as a } \\
\text { dummy, with dummies for every size of the family }\end{array}$ \\
\hline Gender & Dummy: 1 for girls, 0 for boys \\
\hline
\end{tabular}

\footnotetext{
${ }^{26}$ This is an internationally comparable and standardised method of ranking the parents profession according to their (socioeconomic) status (see Ganzeboom et al., 1992). The index is used as a proxy for income and wealth. Direct information on income and wealth could not be obtained, because students filled in the background survey. This might have an influence on the results. Björklund \& Jäntti (1994) report in their paper that when using direct income measures instead of proxies like education and occupation, the sibling effect is either substantially reduced or disappears fully.
} 


\section{Results}

\section{a. General findings}

In a first step, we analyse the impact of the number of siblings on individual test scores in reading literacy in the full sample with all countries. Regression 1 in table 3 shows the coefficient of the linear specification of the sibling variable with no control variables added.

Table 3: Regression on reading literacy ${ }^{27}$

\begin{tabular}{|c|c|c|c|c|}
\hline Regressions & 1 & 2 & 3 & 4 \\
\hline $\begin{array}{l}\text { Independent } \\
\text { Variables }\end{array}$ & Coefficient & Coefficient & Coefficient & Coefficient \\
\hline Constant & $6.350^{*}$ & $6.088^{*}$ & $6.240^{*}$ & $6.235^{\star}$ \\
\hline ISEI & & $0.003^{*}$ & $0.001^{*}$ & $0.001^{*}$ \\
\hline $\begin{array}{l}\text { Parents employment } \\
\text { situation }\end{array}$ & & $0.088^{*}$ & $0.038^{*}$ & $0.038^{*}$ \\
\hline Fathers education & & & 0.001 & 0.001 \\
\hline Mothers education & & & $0.007^{*}$ & $0.007^{*}$ \\
\hline $\begin{array}{l}\text { Closeness to } \\
\text { education }\end{array}$ & & & $0.689^{*}$ & $0.689^{*}$ \\
\hline Parents foreign born & & & $-0.043^{*}$ & $-0.042^{*}$ \\
\hline Student foreign born & & & $-0.018^{*}$ & $-0.018^{*}$ \\
\hline $\begin{array}{l}\text { Other language than } \\
\text { official language }\end{array}$ & & & $-0.039^{*}$ & $-0.039^{*}$ \\
\hline Single headed family & & & $-0.011^{\star *}$ & $-0.010^{*}$ \\
\hline Mixed family & & & $-0.018^{*}$ & $-0.017^{*}$ \\
\hline Other family & & & $-0.057^{*}$ & $-0.055^{*}$ \\
\hline Girl & & & $0.056^{*}$ & $0.056^{*}$ \\
\hline$N S I B$ & $-0.029^{*}$ & $-0.019^{*}$ & $-0.012^{*}$ & -0.004 \\
\hline NSIB squared & & & & $-0.001^{* *}$ \\
\hline $\begin{array}{l}\text { Country dummies } \\
\text { added }\end{array}$ & YES & YES & YES & YES \\
\hline Adjusted $R^{2}$ & 0.06 & 0.16 & 0.30 & 0.30 \\
\hline Number of observations & 56190 & 52444 & 46143 & 46143 \\
\hline
\end{tabular}

${ }^{*},{ }^{* *}$ Significance at the $1 \%$ level and the $5 \%$ level respectively; the reference person is male, lives in a classical family with both parents (for regressions $3 \& 4$ ), his mother tongue being the local language. All observations are weighted. The dependent variable is in a log-linear specification.

The coefficient is highly significant, but its magnitude is not overly impressive. In regression 2 we add control variables that represent the economic situation of the household, in regression 3 we add the rest of our structural variables, in regression 4

\footnotetext{
${ }^{27}$ One standard deviation of the log reading literacy score is 0.1999 . All regressions were run on Stata 6.0. No imputation of missing observations was carried out. Tests for heteroskedasticity (CookWeisberg) and for omitted variables (Ramsey regression specification error test) were made. The hypotheses of homoskedasticity and of no omitted variables could not be rejected.
} 
we add the squared term of the number of siblings in order to make a first test of the assumption of linearity. In all regressions we include country dummies to account for structural differences between the six countries. The family size effect is significant and negative. In the simple version, where we do not account for any differences between the families other than the size (regression 1), the effect amounts to -0.14 of one standard deviation in reading literacy per additional child. The inclusion of additional control variables reduces this effect to $-0.06^{28}$, but the family size variable remains significant. The inclusion of the squared term shows, however, that the family size effect is not linear.

Table 4: $\quad$ Regression on reading literacy with country specific effects ${ }^{29}$

\begin{tabular}{|c|c|c|c|c|}
\hline Regressions & 1 & 2 & 3 & 4 \\
\hline Independent Variables & Coefficient & Coefficient & Coefficient & Coefficient \\
\hline NSIB & $-0.009^{*}$ & -0.002 & $-0.004^{* *}$ & \\
\hline NSIB Belgium & $-0.033^{*}$ & $-0.029^{*}$ & $-0.019^{*}$ & \\
\hline NSIB Canada & -0.005 & $-0.006^{\star \star}$ & -0.004 & \\
\hline NSIB France & $-0.018^{*}$ & $-0.012^{*}$ & -0.005 & \\
\hline NSIB Germany & $-0.030^{*}$ & $-0.024^{*}$ & $-0.010^{*}$ & \\
\hline NSIB Switzerland & $-0.013^{*}$ & $-0.012^{*}$ & -0.007 & \\
\hline NSIB squared & & & & $-0.001^{*}$ \\
\hline NSIB squared Belgium & & & & $-0.003^{*}$ \\
\hline NSIB squared Canada & & & & -0.000 \\
\hline NSIB squared France & & & & -0.001 \\
\hline NSIB squared Germany & & & & $-0.002^{*}$ \\
\hline NSIB squared Switzerland & & & & $-0.001^{* *}$ \\
\hline Country dummies added & YES & YES & YES & YES \\
\hline Control variables added & NO & YES & YES & YES \\
\hline Adjusted $\mathrm{R}^{2}$ & 0.07 & 0.16 & 0.30 & 0.30 \\
\hline Number of observations & 56190 & 52444 & 46134 & 46134 \\
\hline
\end{tabular}

Table 3 shows comparable results as found in Wolter \& Coradi Vellacott (2002) and proves at least, that the significant family-size effect is not particular to Switzerland. In order to analyse, whether there are differences between countries, we discuss four types of analyses, three with the full sample of observations and one with the national sub-samples. In the first analysis with the full sample (table 4) we use the linear specification of the family size and interaction terms for this variable with the countries analysed. In the country specific analysis (table 5), we use dummies for the family size instead.

The results in table 4 show that family-size effects are significant in all countries but that by adding the control variables, differences between countries disappear

\footnotetext{
${ }^{28}$ The size of the effect is almost identical as the one found only for Switzerland.

${ }^{29}$ The control variables in each regression are the same as in table 3.
} 
partially. In the regression (no.3) with all control variables added, only Belgium and Germany have a statistically significant stronger effect than Finland. If we add a squared term of the number of siblings (no.4), Switzerland has also a stronger effect than Finland. It does not surprise that the countries with the higher degree of social differentiation in the PISA results (Belgium, Germany and Switzerland; see table 1), also have a stronger family-size effect than Finland, Canada and France.

Finally we show the results for the full sample with dummies for the family size, where we add an interaction with the test language and the family size (table 6) and an interaction with the quartiles of the ISEI variable (table 7), to test whether there are significant differences between students with the test-language and others and between students coming from different socioeconomic background - over the whole sample of all countries.

\section{b. Country-wise effects and differentiation according to test language and ISEI}

Table 5a: Regression on reading literacy country wise

\begin{tabular}{llll}
\hline \hline \multicolumn{1}{c}{$\begin{array}{c}\text { Countries } \\
\text { Independent Variables }\end{array}$} & Belgium & Canada & Finland \\
\hline 1 sibling & -0.000 & $-0.015^{* *}$ & 0.000 \\
2 siblings & $-0.019^{* *}$ & $-0.026^{*}$ & 0.000 \\
3 siblings & $-0.040^{*}$ & $-0.026^{*}$ & -0.003 \\
4 siblings & $-0.060^{*}$ & $-0.046^{*}$ & -0.015 \\
More than 4 siblings & $-0.115^{*}$ & $-0.051^{*}$ & $-0.048^{*}$ \\
& & & \\
SD dependent variable & 0.222 & 0.189 & 0.166 \\
Control variables added & YES & YES & YES \\
Adjusted R ${ }^{2}$ & 0.297 & 0.205 & 0.239 \\
Number of observations & 5036 & 25245 & 4133 \\
\hline ", ${ }^{* *}$ Significance at the 1\% level and the 5\% level respectively. All observations are \\
weighted. The dependent variable is in a log-linear specification.
\end{tabular}

The differences between the linear and the non-linear specification show, however, that the size effects within countries are distributed differently. Tables $5 a$ and $5 b$ show the results within countries and the dummy specification of the family size. 
Table 5b: Regression on reading literacy country wise

\begin{tabular}{lccc}
\hline \hline \multicolumn{1}{c}{ Countries } & France & Germany & Switzerland \\
Independent Variables & & & \\
\hline 1 sibling & -0.001 & -0.002 & 0.004 \\
2 siblings & -0.003 & -0.009 & -0.006 \\
3 siblings & $-0.049^{*}$ & -0.021 & -0.009 \\
4 siblings & $-0.044^{*}$ & -0.018 & $-0.045^{\star *}$ \\
More than 4 siblings & $-0.047^{*}$ & $-0.119^{*}$ & $-0.061^{\star *}$ \\
& & & \\
SD dependent variable & 0.190 & 0.226 & 0.210 \\
Control variables added & YES & YES & YES \\
Adjusted $R^{2}$ & 0.328 & 0.326 & 0.373 \\
Number of observations & 3516 & 3562 & 4808 \\
\hline " $^{* *}$ Significance at the 1\% level and the 5\% level respectively. All observations are weighted. \\
The dependent variable is in a log-linear specification.
\end{tabular}

According to the results, countries can be divided into four categories (see table 6). Although family-size effects can be observed in all countries analysed, the patterns are quite different. The magnitude of effects ranges from less than one third (Finland) to more than one half (Belgium and Germany) of one standard deviation of reading literacy in large families.

Table 6:

\begin{tabular}{|l|c|c|}
\hline \multicolumn{1}{|c|}{ Criteria } & $\begin{array}{c}\text { In most family } \\
\text { sizes }\end{array}$ & Only for big families \\
\hline Small effects & $\begin{array}{c}\text { Canada } \\
\text { France }\end{array}$ & Finland \\
\hline Big effects & Belgium & $\begin{array}{c}\text { Germany } \\
\text { Switzerland }\end{array}$ \\
\hline
\end{tabular}

According to the model presented in chapter 3 , we can expect that family-size effects can differ substantially between different social groups and the migrant and native population. Therefore, we analyse these sub-groups of the population separately. In tables $7 \mathrm{a}$ and $7 \mathrm{~b}$, we analyse the family-size effects within countries and subdivide the student population in those who were assessed in their mother tongue and those whose mother tongue was different from the test language. We see the test language as the best indicator for cultural distance and better suited to our purposes than the place of birth, although we still have the place of birth in the control variables. 
Table 7a: Regression on reading literacy country wise (testlanguage vs. not test language)

\begin{tabular}{|c|c|c|c|}
\hline $\begin{array}{l}\text { Countries } \\
\text { Independent Variables }\end{array}$ & Belgium & Canada & Finland \\
\hline 1 sibling test language & 0.006 & -0.013 & 0.001 \\
\hline 2 siblings test language & -0.016 & -0.023 & 0.003 \\
\hline 3 siblings test language & $-0.030^{\star *}$ & -0.025 & -0.000 \\
\hline 4 siblings test language & $-0.043^{\star *}$ & $-0.040^{*}$ & -0.015 \\
\hline More than 4 siblings t. I. & $-0.100^{*}$ & $-0.045^{\star}$ & $-0.041^{* *}$ \\
\hline 1 sibling not test language & -0.021 & -0.021 & -0.021 \\
\hline 2 siblings not test language & $-0.032^{\star \star}$ & $-0.040^{\star \star}$ & -0.037 \\
\hline 3 siblings not test language & $-0.075^{\star} \S$ & -0.022 & -0.046 \\
\hline 4 siblings not test language & $-0.110^{\star} \S$ & $-0.086^{\star} \S$ & -0.018 \\
\hline More than 4 siblings not t. I. & $-0.156^{*}$ & $-0.089^{\star *}$ & $-0.157^{\star *}$ \\
\hline SD dependent variable & 0.222 & 0.189 & 0.165 \\
\hline Control variables added & YES & YES & YES \\
\hline F-test ${ }^{30}$ & $6.62^{*}$ & $5.98^{*}$ & $2.03^{* *}$ \\
\hline Adjusted $R^{2}$ & 0.297 & 0.205 & 0.239 \\
\hline Number of observations & 5036 & 25245 & 4133 \\
\hline
\end{tabular}

${ }^{*},{ }^{* *}$ Significance at the $1 \%$ level and the $5 \%$ level respectively. All observations are weighted. The dependent variable is in a log-linear specification. Reference category is a student growing up in a single-child household. $\S$ denotes the cases, where the coefficients of the students tested in the test language and those not, but coming from the same family size are significantly different, at least at the $10 \%$ level. $^{31}$

Although the size effects seem to be stronger for those who were not tested in their mother tongue, the differences are not statistically significant in the cases of Finland and Germany. The non-significance in some cases might be due to the low number of observations for some of the variables. Especially in the case of Finland, where the number of students not tested in their mother tongue was very small. If we run the same regression for the whole sample of all countries (results not shown here) the differences between the two groups are significant for all family sizes (except for families with 2 children).

Due to the fact, that the migrant population is highly diverse from one country to the other, we tested these effects country-wise, whereas for the socioeconomic groups (divided in quartiles) we present the results only for the full sample (table 8). The testing for each country was made and does not really change the overall picture.

As one can easily see, the family-size effects are pretty much concentrated among the lower half of the socioeconomic distribution with the exception of large families (five and more children). The most important finding is that if you group families from the same socioeconomic background (status) together and control for factors like formal education or place of birth you still find significant differences between family

\footnotetext{
${ }^{30}$ An F-test was performed to test whether the coefficients of all family size variables together are significantly different from 0 , which is the case for all countries.

${ }^{31}$ As an example: The negative coefficient in France for a student coming from a family with two siblings and not speaking the test language $(-0.133)$ is significantly different from the coefficient $(-0.000)$ of a student also coming from a family with two siblings but speaking the test language.
} 
of different size. If one finds significant size-effects within more homogenous subgroups of families, the likelihood that we really observe a resource problem and not just a problem of endogeneity should be high.

Table 7b: Regression on reading literacy country wise (testlanguage vs. not test language)

\begin{tabular}{|c|c|c|c|}
\hline $\begin{array}{l}\text { Countries } \\
\text { Independent Variables }\end{array}$ & France & Germany & Switzerland \\
\hline 1 sibling test language & -0.000 & -0.002 & 0.012 \\
\hline 2 siblings test language & -0.000 & -0.009 & 0.005 \\
\hline 3 siblings test language & $-0.046^{*}$ & -0.023 & 0.006 \\
\hline 4 siblings test language & $-0.043^{\star}$ & -0.014 & -0.024 \\
\hline More than 4 siblings t. I. & $-0.048^{*}$ & $-0.095^{\star}$ & $-0.061^{* *}$ \\
\hline 1 sibling not test language & -0.043 & 0.009 & -0.026 \\
\hline 2 siblings not test language & $-0.113^{\star \star} \S$ & -0.015 & -0.052 \\
\hline 3 siblings not test language & $-0.133^{\star} \S$ & 0.028 & $-0.075^{\star \star} \S$ \\
\hline 4 siblings not test language & $-0.103^{\star \star}$ & -0.079 & $-0.120 * \S$ \\
\hline More than 4 siblings not t. I. & $-0.100^{\star *}$ & $-0.254^{* \star}$ & -0.061 \\
\hline SD dependent variable & 0.190 & 0.226 & 0.210 \\
\hline Control variables added & YES & YES & YES \\
\hline F-test & $6.11^{*}$ & $3.75^{\star}$ & $2.79^{*}$ \\
\hline Adjusted $\mathrm{R}^{2}$ & 0.328 & 0.326 & 0.373 \\
\hline Number of observations & 3516 & 3562 & 4808 \\
\hline
\end{tabular}

Table 8: Regression on reading literacy per ISEI quartile ${ }^{32}$

\begin{tabular}{|c|c|c|c|c|}
\hline ISEI-Quartiles & ISEI 1 & ISEI 2 & ISEI 3 & ISEI 4 \\
\hline $\begin{array}{l}\text { Independent } \\
\text { Variables }\end{array}$ & Coefficient & Coefficient & Coefficient & Coefficient \\
\hline 1 sibling & -0.017 & -0.013 & 0.020 & -0.003 \\
\hline 2 siblings & $-0.030 * \S$ & $-0.022^{* \star} \S$ & 0.119 & 0.004 \\
\hline 3 siblings & $-0.059^{*} \S$ & $-0.045^{\star} \S$ & 0.004 & -0.017 \\
\hline 4 siblings & $-0.046^{*}$ & $-0.069^{*} \S$ & 0.011 & -0.020 \\
\hline More than 4 siblings & $-0.112^{*} \S$ & $-0.059^{*}$ & $-0.067^{*}$ & $-0.042^{* *}$ \\
\hline SD dep. variable & 0.203 & 0.193 & 0.174 & 0.162 \\
\hline $\begin{array}{l}\text { Control variables } \\
\text { added }\end{array}$ & YES & YES & YES & YES \\
\hline Adjusted $R^{2}$ & 0.278 & 0.232 & 0.206 & 0.192 \\
\hline $\begin{array}{l}\text { Number of } \\
\text { observations }\end{array}$ & 13386 & 13569 & 9684 & 9661 \\
\hline
\end{tabular}

\footnotetext{
${ }^{32}$ ISEI values are chunked around four distinct values. We therefore decided not to take the exact limits of each quartile but rather to observe the borders given by the values where observations were concentrated. This results in slightly more observations for the lower two quartiles et vice versa.
} 


\section{c. Family size effects on social interaction and home infrastructure}

So far, we have been testing whether the family size had any significant effect on the educational outcome. One of the advantages of PISA is that besides testing the impact of the family size on educational outcomes, we can directly test our hypothesis, which is that an increasing number of children would reduce the parental resources available per child under given circumstances. The PISA background questionnaire offers different descriptions of parental resources. We therefore tested firstly, which of the resources had a significant effect on reading literacy and subsequently, whether the number of siblings had an effect on the resources available per child. The two kinds of resources we found to explain reading literacy were the intensity of social communication between parents and children (variable "soccom") and having its own room (variable "room"). The latter should give an indication for physical resources at home. The intensity of social communication should reflect the time resources of parents.

Tables 9 and 10 show the regression results. We conducted two forms of regressions in each case. The first analyses country specific differences with an interaction variable, the second uses the full sample and the dummy specification for the familysize, as the size-effects are not completely linear.

Table 9 shows, that the number of siblings affects the probability of having one's own room significantly in all six countries. With the exception of Germany the effects are significantly stronger in all countries than in Finland. The second column in table 9 shows the effects for each size of the family, the third column shows the marginal effects. The results indicate that having three or more siblings reduces the probability that a student has his/her own room by $30 \%$ and more.

A similar effect can be observed for the intensity of social communication. The effect of the number of siblings is significant in all countries and again, this time with the exception of Canada, stronger in all countries than in Finland. Having four or more siblings reduces the social interaction between parents and child by one quarter of a standard deviation of the variable "soccom".

Tables 9 and 10 show the statistical evidence proving that the number of children in a household not only affects the educational outcome but also the process that leads to the outcome. Being born into a family with more children reduces the amount of parental resources per child, also when controlled for all other observable differences between families. 
Table 9: Probit regression on variable "room"

\begin{tabular}{lccc}
\hline Independent Variables & $\begin{array}{c}\text { Regression } \\
\text { siblings }\end{array}$ & $\begin{array}{c}\text { family size } \\
\text { (full sample) }\end{array}$ & $\begin{array}{c}\text { marginal } \\
\text { effects }\end{array}$ \\
\hline NSIB & $-0.179^{*}$ & & \\
NSIB Belgium & $-0.060^{\star *}$ & & \\
NSIB Canada & $-0.064^{*}$ & & \\
NSIB France & $-0.088^{*}$ & & \\
NSIB Germany & 0.045 & & \\
NSIB Switzerland & $-0.077^{\star *}$ & $-0.635^{*}$ & $-0.088^{\star}$ \\
1 sibling & & $-0.986^{*}$ & $-0.172^{*}$ \\
2 siblings & & $-1.239^{*}$ & $-0.294^{\star}$ \\
3 siblings & & $-1.249^{*}$ & $-0.314^{\star}$ \\
4 siblings & & $-1.324^{*}$ & $-0.349^{*}$ \\
More than 4 siblings & & & \\
& & 0.892 & 0.892 \\
Mean dependent variable & 0.892 & YES & YES \\
Control variables added & YES & -12136.20 & \\
Log likelihood & -12178.45 & 0.145 & \\
Adjusted R $R^{2}$ & 0.141 & 46300 & \\
Number of observations & 46134 & & \\
\hline
\end{tabular}

${ }^{*}{ }^{* *}$ Significance at the $1 \%$ level and the $5 \%$ level respectively. All observations are weighted. Reference category is a student growing up in a single-child household.

Table 10: Regression on variable "soccom"

\begin{tabular}{|c|c|c|}
\hline Independent Variables & $\begin{array}{l}\text { Number of siblings } \\
\text { country wise }\end{array}$ & $\begin{array}{c}\text { family size } \\
\text { (full sample) }\end{array}$ \\
\hline NSIB & $-0.026^{*}$ & \\
\hline NSIB Belgium & $-0.068^{*}$ & \\
\hline NSIB Canada & -0.006 & \\
\hline NSIB France & $-0.033^{\star *}$ & \\
\hline NSIB Germany & $-0.047^{\star *}$ & \\
\hline NSIB Switzerland & $-0.042^{* \star}$ & \\
\hline 1 sibling & & $-0.0855^{*}$ \\
\hline 2 siblings & & $-0.1693^{*}$ \\
\hline 3 siblings & & $-0.2010^{*}$ \\
\hline 4 siblings & & $-0.2317^{*}$ \\
\hline More than 4 siblings & & $0.2893^{*}$ \\
\hline SD dependent variable & 0.944 & 0.944 \\
\hline Control variables added & YES & YES \\
\hline$F(43, N-44)$ & 66.66 & 66.64 \\
\hline Adjusted $\mathrm{R}^{2}$ & 0.111 & 0.111 \\
\hline Number of observations & 46119 & 46285 \\
\hline
\end{tabular}

${ }^{*},{ }^{* *}$ Significance at the $1 \%$ level and the $5 \%$ level respectively. All observations are weighted. Reference category is a student growing up in a single-child household. 


\section{Conclusions}

In this paper, we have shown that the educational outcome of a fifteen-year-old child, as assessed in PISA, depends significantly on the number of siblings in his/her family. The negative effect of a large sibship on the educational performance of a child is even more pronounced, if the parents have a low socioeconomic status and/or the childs' mother tongue is not the test language. The finding that no significant family-size effect can be measured for students coming from a good socioeconomic background and speaking the test language, can be explained by a model that takes into account the nature and the quality of parental resources and the interaction that takes place between siblings.

Although the possibility, that some of the family-size effect might be due to unobserved heterogeneity between parents, can not be ruled out completely, the concentration of size effects within well defined sub-groups of the population and the richness of the observable characteristics of the parental environment speak in favour of a resource effect. An additional argument in favour of this explanation is the finding that observed parental resources that affect educational outcomes also depend significantly on the family-size. Contrary to the known empirical studies in this field, we therefore get direct evidence for the detrimental effect of the family-size on the parental resources available for children.

The family-size effect is observable in all countries analysed in this study but differ significantly between them. The pattern we can detect in these differences shows that countries with generally more homogeneous results in the PISA assessment (Finland, Canada and France) also show smaller family-size effects. Therefore, we can assume that at least a part of the more equitable results in these countries can be attributed to policies that compensate for the negative effects the number of siblings has on the amount of parental resources for each child.

Regarding to the students that were not tested in their mother tongue, the familysize effect is stronger than for those who were tested in their own language. We assume that the language is a proxy for the cultural distance of migrants to their host country and that besides the quantity of parental resources there is also a quality aspect to take into account. In Finland, with a very low number of students not being tested in their mother tongue, as well as in Canada (only a small difference) and Germany, we do not find significant differences between migrants and natives, concerning the family-size effect. Notable differences, however, are found in France, Belgium and Switzerland. For the latter two countries, this finding is perhaps not surprising as they have the highest share of students not speaking the test language at home, but the same argument does not apply for the case of France.

We can not attribute differences in the pattern of family-size effects between countries to specific policy measures but we can conclude from these differences that there apparently is room for policies to compensate for budget constraints (for which the family-size is used as an indicator) and other effects.

Additionally, we do not know when an intervention would be most promising. The parental resources available for children are not stable over the whole childhood 
and there is a controversy, whether early interventions would be more effective or later ones. ${ }^{33}$

In the past, equity in education was associated with gender, race and other characteristics of the students but less so with their socioeconomic background. ${ }^{34}$ The present findings indicate that some re-thinking is necessary and that besides socio-demographic characteristics of students, socioeconomic status still is an important source of inequity in the educational system.

\footnotetext{
${ }^{33}$ Literature on early childhood generally finds positive effects of public provision of child-care. Other studies find less important effects of parental resources during the early childhood and more important effects in later stages of the school career (e.g. Jenkins \& Schluter, 2002).

${ }^{34}$ Only recently, empirical studies stress again the importance of the socioeconomic status of parents (e.g. Black \& Sufi, 2002 in a similar context).
} 


\section{Literature}

Acemoglu, D., Pischke, J.-S. (2001): Changes in the Wage Structure, Family Income, and Children's Education, European Economic Review, Vol. 45, pp.890-904.

Bauer, T., Gang, I.N. (2001): Sibling Rivalry in Educational Attainment: The German Case, Labour, Vol. 15(2), pp. 237-255.

Becker, G.S. (1960): An Economic Analysis of Fertility, in: Coale et al. Demographic and Economic Change in Developed Countries, Princeton: National Bureau of Economic Research, pp. 209-240.

Becker, G.S., Tomes, N. (1986): Human Capital and the Rise and Fall of Families, Journal of Labor Economics, Vol. 4(3), pp. 1-39.

Björklund, A., Jäntti, M. (1994): The Impact of the Number of Siblings on Men's Adult Earnings: Evidence from Finland, Sweden and the United States, Paper presented at the EALE-conference in Warzaw.

Black, S.E., Sufi, A. (2002): Who goes to College? Differential Enrollment by Race and Family Background, in: NBER Working Paper No. 9310.

Bourdieu, P. (1983): Oekonomisches Kapital, kulturelles Kapital, soziales Kapital, in: R. Krekel (Ed.), Soziale Ungleichheiten. Soziale Welt, Sonderband 2, Göttingen: Schwartz, pp. 183-198.

Butcher, K.F., Case, A. (1994): The Effect of Sibling Sex Composition on Women's Education and Earnings, Quarterly Journal of Economics, Vol. CIX (3), pp. 531-563.

Coleman, J.S. (1988): Social Capital in the Creation of Human Capital, American Journal of Sociology, Vol. 94, pp. 95-120.

Coradi Vellacott, M., Wolter, S.C. (2002): Origine Social et Egalité des Chances, in: OFS+CDIP (Eds.): Préparés pour la vie?, Neuchâtel: Office Fédéral de la Statistique, pp. 88-109.

DeVoretz, D.J, Hinte, H, Werner, C. (2002): How much Language is enough? Some Immigrant Language Lessons from Canada and Germany, in: IZA Discussion Paper No. 555, Bonn: IZA.

Duru-Bellat, M. (2000): Social Inequalities in the French Education System: The joint Effect of Individual and Contextual Factors, in: Journal of Education Policy, Vol. 15 (3), pp. 30-40.

Duru-Bellat, M., Kieffer, A. (2000): Inequalities in Educational Opportunities in France: Educational Expansion, Democratization or shifting Barriers? in: Journal of Education Policy, Vol. 15 (3), pp. 333-352.

Dustmann, C. (2001): Parental Background, Primary to Secondary School Transitions, and Wages, IZA Discussion Paper No. 367, Bonn: IZA.

Ermisch, J., Francesconi, M. (2001): Family Matters: Impacts of Family Background on Educational Achievements, Economica, pp. 137-156.

Fertig, M., Schmidt, C. M. (2002): The Role of Background Factors for Reading Literacy: Straight National Scores in the PISA 2000 Study, IZA Discussion No. 545, Bonn: IZA. 
Gang, I.N., Zimmermann, K.F. (2000): Is Child like Parent?, Journal of Human Resources, Vol. XXXV (3), pp. 550-569.

Ganzeboom, H.B.G., De Graaf, P. and Treiman, D.J. (1992): A Standard International Socioeconomic Index of Occupational Status, Social Science Research, Vol. 21(1), pp. 1-56.

Garg, A., Morduch, J. (1998): Sibling Rivalry and the Gender Gap: Evidence from Child Health Outcomees in Ghana, Journal of Population Economics, Vol. 11, pp. 471-493.

Hanushek, E.A. (1992): The Trade-off between Child Quantity and Quality, Journal of Political Economy, Vol. 100 (1), pp. 84-117.

Hauser, R.M., Kuo, H.-H. D. (1998): Does the Gender Composition of Sibships Affect Women's Educational Attainment?, Journal of Human Resources, Vol. XXXIII (3), pp. 644-657.

Jenkins, S.P., Schluter, C. (2002): The Effect of Family Income during Childhood on Later Life Attainment: Evidence from Germany, in: IZA Discussion Paper, No. 604, Bonn: IZA.

Joesch, J.M., Hiedemann, B.G. (2002): The Demand for Nonrelative Child Care among Families with Infants and Toddlers: A Double-Hurdle Approach, Journal of Population Economics, Vol. 15(2), pp. 495-526.

Kaestner, R. (1997): Are Brothers Really Better? Sibling Sex Composition and Educational Achievement Revisited, Journal of Human Resources, Vol. XXXII (2), pp. 250-284.

Kessler, D. (1991): Birth Order, Family Size, and Achievement: Family Structure and Wage Determination, Journal of Labor Economics, Vol. 9 (4), pp. 413-426.

Lee, V.E., Burkam, D.T. (2002): Inequality at the Starting Gate - Social Background Differences in Achievement as Children begin School, Washington: Economic Policy Institute.

Lindert, P.H. (1977): Sibling Position and Achievement, Journal of Human Resources, Vol. XII (2), pp. 198-219.

Lundholm, M., Ohlsson, H. (2002): Who takes Care of the Children? The QuantityQuality Model Revisited, Journal of Population Economics, Vol. 15(3), pp. 455-461.

Mare, R.D., Chen, M.D. (1986a): Sibship Size and Educational Stratification. Rejoinder to Blake, American Sociological Review, Vol. 51, pp. 418-420.

Mare, R.D., Chen, M.D. (1986b): Further Evidence on Number of Siblings and Educational Stratification, American Sociological Review, Vol. 51, pp. 403-12.

OECD (2001): Knowledge and Skills for Life, First Results from PISA 2000, Paris: OECD.

Reay, D., Davies, J., David, M., Ball, S.J. (2001): Choices of Degree or Degree of Choices? Class, 'Race' and the Higher Education Choice Process, in: Sociology, Vol. 35 (4), pp. 855-874.

Schnabel, K.U., Alfeld, C., Eccles, J.S., Köller, O, Baumert, J. (2002): Parental Influence on Students' Educational Choices in the United States and Germany: Different Ramifications - Same Effect?, in: Journal of Vocational Behavior, Vo. 60, pp. 178-198. 
Schoon, I., Parsons, S. (2002): Teenage Aspirations for future Careers and Occupational Outcomes, in: Journal of Vocational Behavior, Vol. 60, pp. 262-288.

Stafford, F.P. (1987): Women's Work, Sibling Competition, and Children's School Performance, The American Economic Review, Vol. 77 (5), pp. 972-980.

Sullivan, A. (2001): Cultural Capital and Educational Attainment, in: Sociology, Vol. 35 (4), pp. 893-912.

Willms, J.D. (1986): Social Class Segregation and its Relationship to Pupils Examination Results in Scotland, American Sociological Review, Vol. 51, pp. 224241.

Wolter, S.C., Coradi Vellacott, M. (2002): Sibling Rivalry: A Look at Switzerland with PISA Data, in: IZA Discussion Papers No. 594, Bonn: IZA. 


\section{IZA Discussion Papers}

\begin{tabular}{|c|c|c|c|c|}
\hline No. & Author(s) & Title & Area & Date \\
\hline 718 & E. Schlicht & Consistency in Organization & 1 & $02 / 03$ \\
\hline 719 & $\begin{array}{l}\text { J. Albrecht } \\
\text { P. Gautier } \\
\text { S. Vroman }\end{array}$ & $\begin{array}{l}\text { Equilibrium Directed Search with Multiple } \\
\text { Applications }\end{array}$ & 3 & $02 / 03$ \\
\hline 720 & T. Palokangas & $\begin{array}{l}\text { Labour Market Regulation, Productivity- } \\
\text { Improving R\&D and Endogenous Growth }\end{array}$ & 3 & $02 / 03$ \\
\hline 721 & $\begin{array}{l}\text { H. Battu } \\
\text { M. Mwale } \\
\text { Y. Zenou }\end{array}$ & $\begin{array}{l}\text { Do Oppositional Identities Reduce Employment } \\
\text { for Ethnic Minorities? }\end{array}$ & 1 & $02 / 03$ \\
\hline 722 & $\begin{array}{l}\text { C. K. Spiess } \\
\text { F. Büchel } \\
\text { G. G. Wagner }\end{array}$ & $\begin{array}{l}\text { Children's School Placement in Germany: Does } \\
\text { Kindergarten Attendance Matter? }\end{array}$ & 6 & $02 / 03$ \\
\hline 723 & $\begin{array}{l}\text { M. Coles } \\
\text { B. Petrongolo }\end{array}$ & $\begin{array}{l}\text { A Test between Unemployment Theories Using } \\
\text { Matching Data }\end{array}$ & 3 & $02 / 03$ \\
\hline 724 & $\begin{array}{l}\text { J. T. Addison } \\
\text { R. Bailey } \\
\text { W. S. Siebert }\end{array}$ & $\begin{array}{l}\text { The Impact of Deunionisation on Earnings } \\
\text { Dispersion Revisited }\end{array}$ & 2 & $02 / 03$ \\
\hline 725 & S. Habermalz & An Examination of Sheepskin Effects Over Time & 1 & $02 / 03$ \\
\hline 726 & S. Habermalz & $\begin{array}{l}\text { Job Matching and the Returns to Educational } \\
\text { Signals }\end{array}$ & 1 & $02 / 03$ \\
\hline 727 & $\begin{array}{l}\text { M. Raiser } \\
\text { M. Schaffer } \\
\text { J. Schuchardt }\end{array}$ & Benchmarking Structural Change in Transition & 4 & $02 / 03$ \\
\hline 728 & $\begin{array}{l}\text { M. Lechner } \\
\text { J. A. Smith }\end{array}$ & What is the Value Added by Caseworkers? & 6 & $02 / 03$ \\
\hline 729 & $\begin{array}{l}\text { A. Voicu } \\
\text { H. Buddelmeyer }\end{array}$ & $\begin{array}{l}\text { Children and Women's Participation Dynamics: } \\
\text { Transitory and Long-Term Effects }\end{array}$ & 3 & $02 / 03$ \\
\hline 730 & $\begin{array}{l}\text { M. Piva } \\
\text { M. Vivarelli }\end{array}$ & $\begin{array}{l}\text { Innovation and Employment: Evidence from } \\
\text { Italian Microdata }\end{array}$ & 2 & $02 / 03$ \\
\hline 731 & $\begin{array}{l}\text { B. R. Chiswick } \\
\text { N. DebBurman }\end{array}$ & $\begin{array}{l}\text { Educational Attainment: Analysis by Immigrant } \\
\text { Generation }\end{array}$ & 1 & $02 / 03$ \\
\hline 732 & $\begin{array}{l}\text { A. Falk } \\
\text { A. Ichino }\end{array}$ & Clean Evidence on Peer Pressure & 5 & $03 / 03$ \\
\hline 733 & $\begin{array}{l}\text { S. Wolter } \\
\text { S. Denzler }\end{array}$ & $\begin{array}{l}\text { Wage Elasticity of the Teacher Supply in } \\
\text { Switzerland }\end{array}$ & 2 & $03 / 03$ \\
\hline 734 & S. Wolter & Sibling Rivalry: A Six Country Comparison & 2 & $03 / 03$ \\
\hline
\end{tabular}

An updated list of IZA Discussion Papers is available on the center's homepage www.iza.org. 